\title{
Mobility as a Service: A solution to traffic congestion in Florida
}

\author{
Taraneh Ardalan* \\ Department of Civil and Environmental Engineering, University of Pittsburgh, USA
}

Submission: July 14, 2020; Published: September 07, 2020

*Corresponding author: Taraneh Ardalan, Department of Civil and Environmental Engineering, University of Pittsburgh, USA

\begin{abstract}
The needs for the growing and aging population, increased urbanization, and sustainability goals are all challenging the cities and suburban areas in different ways. As a result, administrators are dealing with the effects of traffic congestion, under-utilized public transit systems, limited funds, and increased problems with environmental impacts. Even if still emerging, many regard mobility as a Service (MaaS) to be an approach that could help authorities develop transport services and reduce some of the problems facing the system. However, several factors are being involved in MaaS that should be considered for specific regions with specific features. This article is the author's opinion regarding the application of MaaS in the region of Florida, United States.
\end{abstract}

Keywords: Traffic congestion; Mobility as a service; Public transportation

\section{Introduction}

The future of transportation is defined by autonomous vehicles, big data analytics, innovative technologies, the internet of things, and customer service in the digital age. The new concept in transportation that holds the promise of offering urban mobility with a paradigm shift is Mobility as a service (MaaS). The idea of MaaS can be simply interpreted as the use of a single application on everyone's phones to connect and pay for various modes of transportation within a city or beyond it. The application will provide options for choosing the most appropriate mode of transportation for a traveler in terms of time, convenience, cost, and etc. Nowadays, MaaS could be easily applied through the current mass adoption of smartphones and social media as well as the omnipresent internet connection. In the past decade, Florida's population has grown by more than 3 million people and the predictions show that, this trend will continue by 2040 . The population of Florida will increase with at least 5 million people joining this state. Besides, as Florida is known for the surprising number of tourists each year, statistics indicate that in 2018 the state had 126.1 million visitors, an increase of 6 percent from the 2017 record which is around 6 times of the population. According to the Bureau of Workforce Statistics and Economic Research 2019 , the state's economy relies mainly on tourism, agriculture, and transportation which all of them are tied with how to transfer people and goods. Therefore, transportation plays a key role in the economy of the area.
Florida's highway system contains 1,495 miles of interstate highway, and 10,601 miles of the non-interstate highway, such as State Highways and U.S. Highways. Moreover, due to the logistic location of Florida, there are 15 public seaports that are playing a critical role in the lives of not only the residents of Florida but also the whole nation by transferring all the supplies required for food, clothes, building materials, automobiles, and almost everything involved in daily lives flows through the ports. In addition, Florida has 131 public airports. Florida's four large hub airports, as classified by the Federal Aviation Administration are Orlando International Airport, Miami International Airport, Fort Lauderdale-Hollywood International Airport, and Tampa International Airport. In terms of the railroad, Florida is accompanied by Intercity Rail which is the southern terminus of the Amtrak Auto Train, originating in Lorton, Virginia, south of Washington, DC. Furthermore, Virgin Trains USA is a high-speed service that connects Miami, Ft. Lauderdale, and West Palm Beach. Orlando is expected to be reached by the end of 2020. There are also other commuter rail systems in different metro areas of Florida such as Tri-rail and Sun-rail in the South Florida and Greater Orlando respectively.

Looking at public transportation in Florida and considering the types of land use and people's lifestyle, we can reach the point that Florida's transit system is not thoroughly comprehensive 
because of several factors such as the age of residents, weather conditions, location of facilities, and etc. Thus, only a few cities in Florida are offering public transit, for instance, Miami, Orlando, Tampa, and Jacksonville. As an example, the Miami MetroRail is the state's only rapid transit system and only about $15 \%$ of Miamians use public transit daily. This number proves that due to the low demand for public transit, it might not worth it to invest money in this sector of transportation. However, in order to generate and operate MaaS, there are some fundamental requirements that must be fulfilled. The operating conditions of MaaS in an urban area can be summarized as the availability of a wide range of transport modes, accessibility of real-time data from transportation operators to a third party, and approachability of required infrastructure from transportation operators regarding services through e-ticket or e-payment. Above all, coordinated cooperation between stakeholders is necessitated in order to allow the third party to sell their services.

Although Florida is recently facing remarkable difficulties regarding the increase in population and continuously congestion on its corridors, but most of the cities in Florida are not qualified for functioning as the candidates for implementing MaaS with their current conditions since they lack the presence of reach infrastructure for the transit system just as the first condition of MaaS. However, the necessity of connecting to such technology should not have been neglected. Especially, with the high demand for fast, reliable, accessible, and convenient multimodal transportation for both passengers and freight, it is the time to build up the requirements for the implementation of the MaaS in Florida in the role of a successful solution. MaaS uses advanced analytics to combine the user's trip history, current traffic circumstances, data from other commuters, and information from different modes of travel across the city to provide a set of tailored seamless options. The expenses can be paid by the mile and the insurance is adjustable per trip, route, and mode of transportation. Since physical assets are smart and connected allowing consistent real-time monitoring. The digital infrastructure provides users with high-speed connectivity for a smooth experience during the trip. All these features address the comprehensive requirements for an easier life and at the same time decreases the congestion, travel time, delays, pollutions, costs and accidents. The numerous new sustainable urban mobility solutions such as ridesharing, car-sharing, e-tickets, e-scooters and the generally app-based market can be all considered as the fundamentals of MaaS. The scope to combine all available options and to use a single app to access and pay for all transport modes is nothing but joining the MaaS. Alike with all innovative and novel technologies, MaaS is also coupled with various challenges, but sooner or later it is going to be the inseparable component of everyday' lives. Therefore, to be prepared for it, Florida needs to start it today, because this is the solution.

\section{Conclusion}

Mobility as a Service offers a transformative improvement to various aspects of transportation such as social, economic, and environmental results. It is vital to note that MaaS implementation and wide deployment could be faced with challenges and could have unexpected consequences as well. The various levels of demographic, cultural, infrastructure, and technology availability between regions and across rural and urban areas need to be carefully planned to suit the region.

Your next submission with Juniper Publishers
will reach you the below assets
- Quality Editorial service
- Swift Peer Review
- Reprints availability
- E-prints Service
- Manuscript Podcast for convenient understanding
- Global attainment for your research
- Manuscript accessibility in different formats
( Pdf, E-pub, Full Text, Audio)
- Unceasing customer service
Track the below URL for one-step submission
https://juniperpublishers.com/online-submission.php

